\title{
3D-LAYOUTS OF MACHINE TOOLS FOR MULTIPURPOSE MACHINING OF ROTARY COMPONENTS
}

\author{
Lachezar Stoev, Stoil Bozhikov
}

Original scientific paper

In the paper is presented a concept for design of different 3D-layouts of one- and two-carriage machine tools for combined machining of chuck and centre to centre type workpieces based on a modular principle. New 3D-layouts are offered for consecutive or simultaneous, one-sided or bilateral machining of chuck and centre-to-centre type components. The first section of the paper presents design features and technological capabilities of typical representatives of the so-called single-carriage machine tools as 3D-layouts. The second section presents typical 3D-layouts of double-carriage machine tools where two parallel guideways are used for guiding each one of the carriages. The effective integration of the rough and finishing machining can be accomplished only by new machine tools for chuck or centre-to-centre type workpieces referred in the present paper as "multipurpose".

Keywords: 3D-layouts; multipurpose machining; one- and two-carriage machine tools

3D-prikazi alatnih strojeva za višestruku obradu rotirajućih dijelova

Izvomi znanstveni članak

U radu je predstavljen koncept za izradu različitih 3D-prikaza alatnih strojeva s jednom ili dvije klizne staze za kombiniranu obradu steznih i obradaka tipa od središta do središta, utemeljenih na principu modularnosti. Novi se 3D-prikazi nude za uzastopnu ili istovremenu, jednostranu ili dvostranu obradu steznih i dijelova tipa od središta do središta. U prvom dijelu rada prikazuju se projektne i tehnološke mogućnosti tipičnih predstavnika tako zvanih alatnih strojeva s jednom kliznom stazom kao 3D-prikazi. U drugom se dijelu daju tipični 3D-prikazi alatnih strojeva s dvije klizne staze gdje se za svaku od staza koriste dvije paralelne vodilice. Učinkovito povezivanje grube i završne obrade može se postići jedino novim alatnim strojevima za stezne i obratke tipa od središta do središta, a oni se u ovom radu spominju kao "višestruki" (multipurpose).

Ključne riječi: 3D-prikazi; višestruka obrada; alatni strojevi s jednom ili dvije klizne staze

\section{Introduction}

In papers $[1,2]$ the new layouts developed for machine tools were presented giving the opportunity to combine rough and finish machining of rotary components on a single machine. The degree of integration of the complete or part of the rough machining with the finish machining depends on the type and machinability of the blanks, the production type and proper selection of design modules [3].

The first section of the paper presents design features and technological capabilities of typical representatives of the so-called single-carriage machine tools as 3D-layouts. Typical for them is the usage as a basic module of a turret compound carriage with a different tooling. The second section presents typical 3D-layouts of double-carriage machine tools where two parallel guideways are used for guiding each one of the carriages.

In various references different names are used for such machine tools as the envisaged: multifunctional, machine tools for complex machining, combined [4], machining centres and multioperational. The last one was used by the authors in previous publications in correspondence with the definition for a machining centre given by CECIMO (European Association of the Machine Tool Industries) [5]: "A machining centre is a machine tool with numerical programme control, which can perform at least two machining operations and is capable of automatic tool changing from a magazine or another similar storage device. As a matter of fact, both in machining centres with magazines and multioperational machine tools with one or more turret heads without magazines no more than one operation is executed in combination with at least two different methods of machining. This is evident from the definition of an operation: a finished part from the technological process performed at a single work place."

That is why in the title and in the text of the present publication the more accurate definition for machine tools of that type is used: "machine tools for machining by combining at least two different methods", or the shorter one "machine tools for combined machining" (MCM). This definition ought to be adopted also for machining centres where the tools are automatically changed from a magazine.

\section{3D-layouts of single carriage machine tools for combined machining}

Fig. 1 shows a 3D-layout of a single carriage machine tool for consecutive combined machining of all one-side placed surfaces of chuck-type components. As all other layouts presented in this publication, it is designed on a modular principle from the following units: bed 1, turret compound slide 2 and headstock 3 with a spindle unit to fix the workpiece with horizontal axis. For the sake of simplicity, the guideways and all units are depicted on a horizontal plane. However, in all layouts they are either inclined or vertical with respect to the horizontal plane. In this way better chip and coolant removal is possible.

The turret compound carriage is capable of numerical traverse and longitudinal movement along the axes $X_{1}$ and $Z_{1}$ and an angular repositioning when rotating around $B_{1}$ axis. Its traverse movement is performed by two traverse slides placed one above the other and each one of them has its own guideways and feed drives for rough and finish machining [6]. By splitting them maintenance of accuracy for diametric dimensions is preserved for a longer service period. 


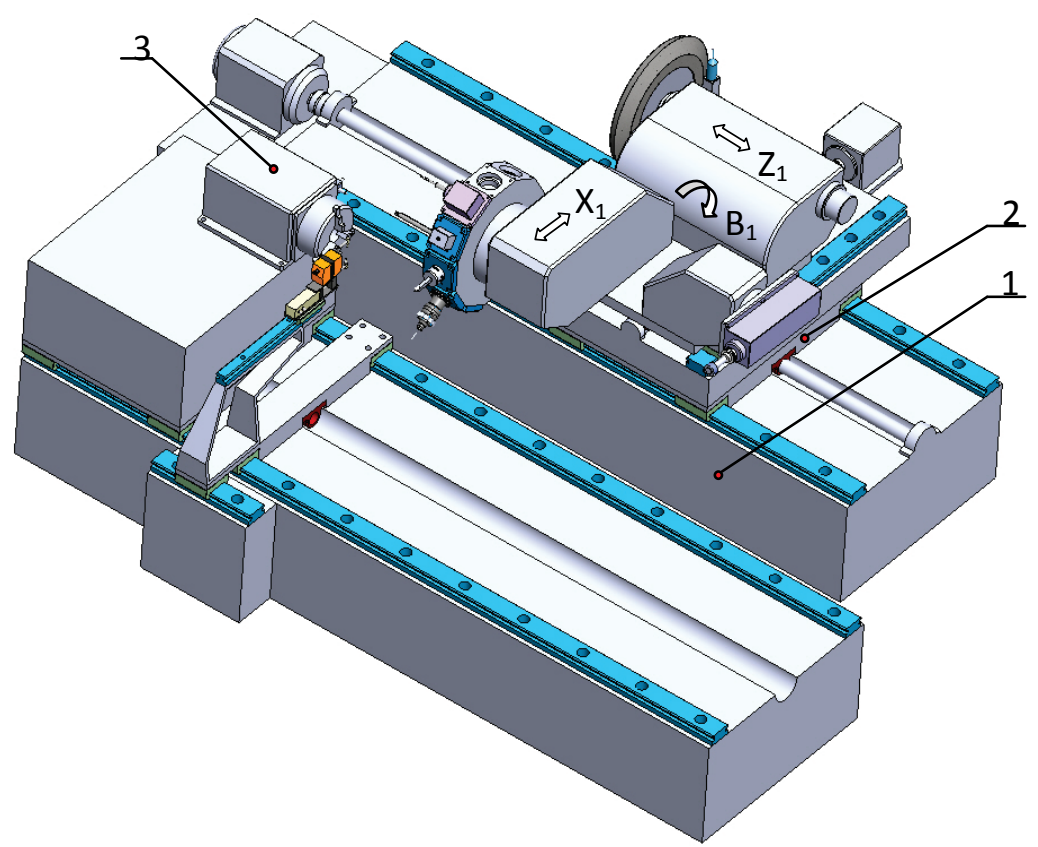

Figure 1 Single carriage machine tool for consecutive one-sided combined machining of chuck type components

In the layout presented in Fig. 1 the carriage is equipped with a spindle unit for internal grinding, a spindle unit for external grinding with a single grinding wheel and a turret head for different tools. The device for longitudinal positioning of the grinding wheel with respect to the workpiece is fixed to the housing of the external grinding spindle; two diamond-point dressers placed on the headstock perform the turning of the wheel.

The layout in Fig. 1 provides consecutive machining on one machine tool and at one setting of all one-side placed internal and external face, cylindrical and tapered surfaces of chuck type components. This is achieved by combining different methods of machining (turning, drilling, boring and grinding) in a single operation $[7,8$,
9, 10, 11]. With this technological sequence, the error from a new positioning of the workpiece is avoided and minimal allowance for grinding can be used. The total machining time is reduced; the wear of the grinding wheels is lessened, which reduces the number and duration of inter-cycle dressings. As a result, the productivity is increased, especially with internal grinding.

Fig. 2 presents a 3D-layout of a single carriage machine tool designed for consecutive combined machining of all one-sided surfaces of centre-type components with two options for their positioning between centres or between a chuck and a centre. The second option is presented in the figure.

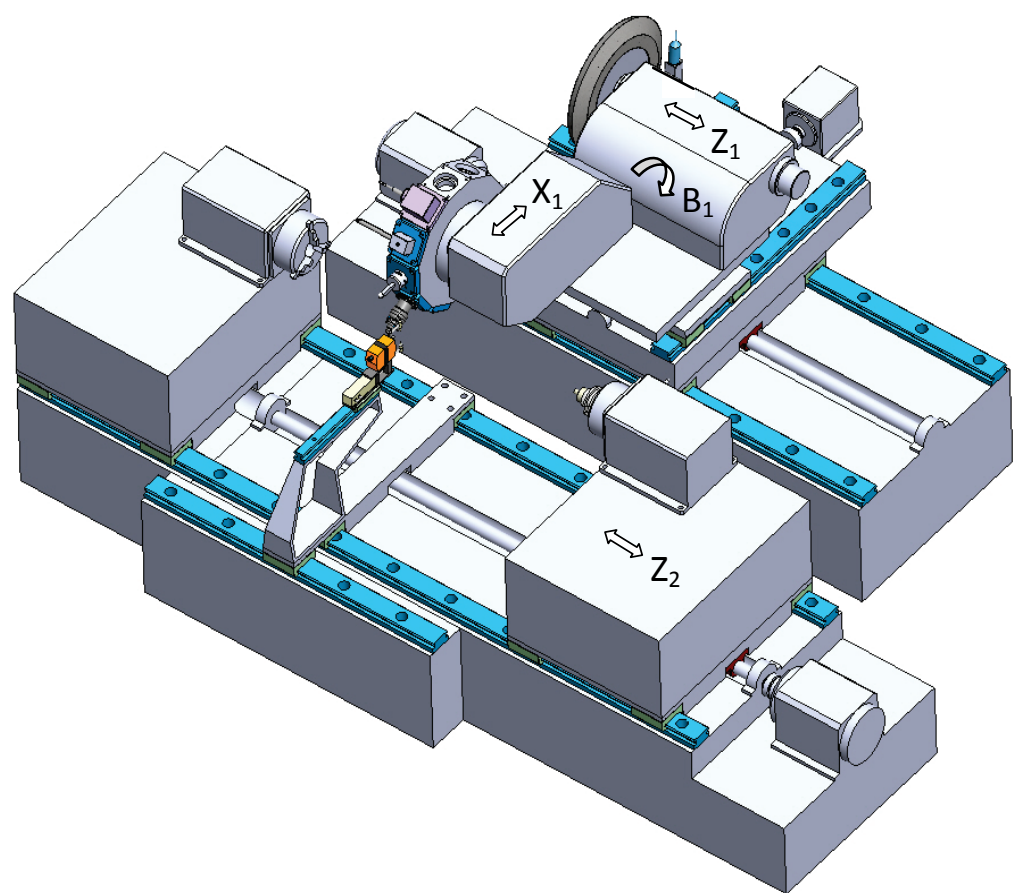

Figure 2 Single carriage machine tool for consecutive one-sided combined machining of centre type components 
The tailstock is placed on the second longitudinal guide way with an additional numerical axis $Z_{2}$ which allows changing the centre-to-centre distance when machining components with different length. The diagram shows the placement of a standard single-dimension or wide-scope active control device used with infeed or traverse grinding [12].

In Fig. 3, a 3D-layout of a general-purpose singlecarriage machine tool with enhanced technological performances is presented compared to the layouts shown in Fig. 1 and 2. It is designed for consecutive combined machining of all one-sided (right) surfaces of centre and chuck-type components at one positioning at random sequence. With it, the headstock may be placed in two positions with an option to rotate around $B_{2}$ axis. In this case an option of positioning of a centre-type part (between two centres) is shown and a special chuck to transfer torque. The machining of left-hand surfaces is possible with a second positioning of the component on the same or another machine tool of the same type. Positioning between centres provides high accuracy of mutual surface positioning of all machined left- and righthand surfaces.

The second position of the headstock is occupied by a spindle unit with a chuck for clamping chuck type components when machining their one-sided surfaces. The machine tools for combined machining with a layout like the one in Fig. 3 are most suitable for medium scale batch production due to the reasonable price of the machine tool and enhanced technological capabilities.

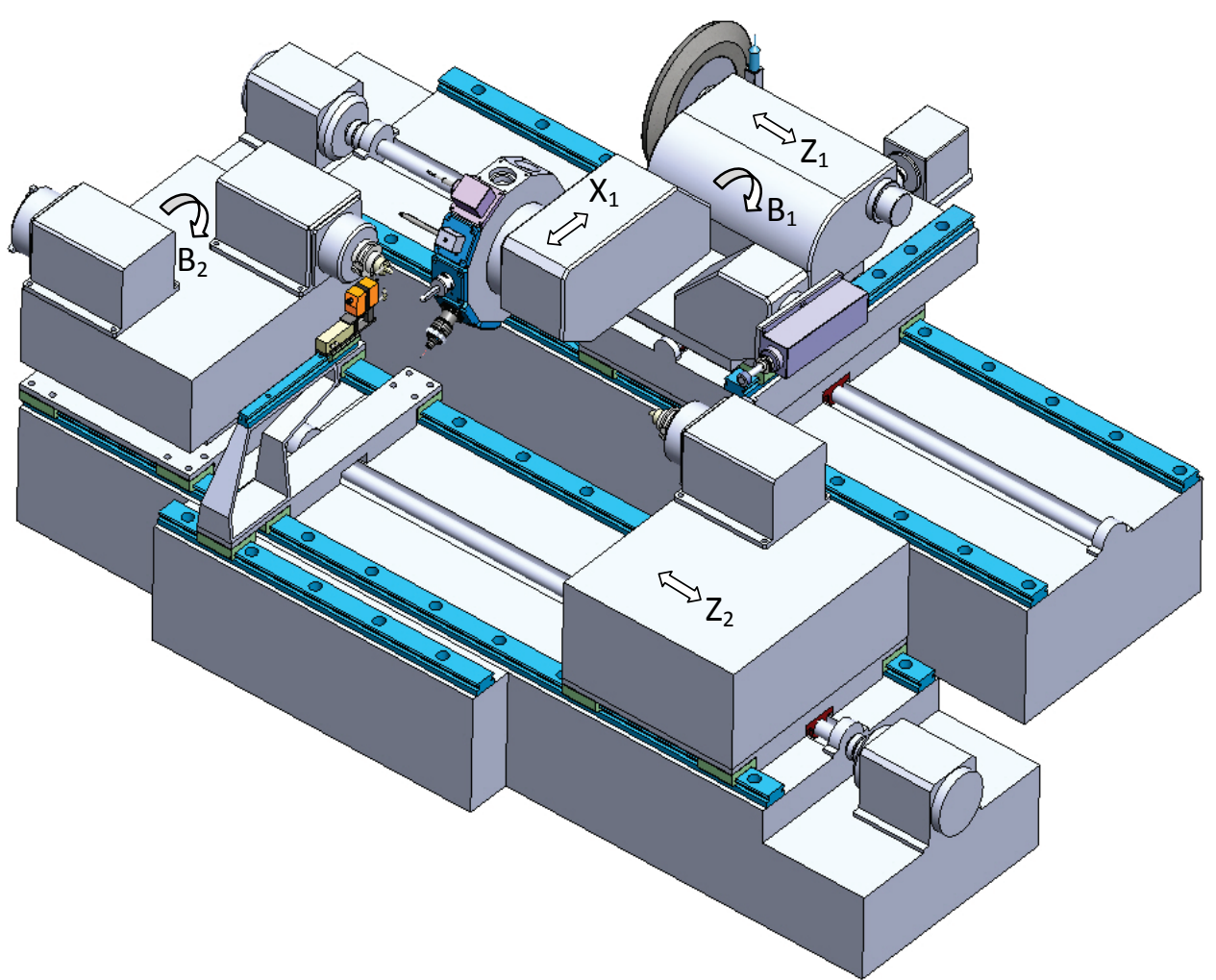

Figure 3 A general purpose single carriage machine tool for consecutive one-sided combined machining in random order of centre and chuck type components

Fig. 4 presents a layout of a single carriage machine tool for consecutive combined bi-lateral machining of chuck type components with stepped external and internal surfaces. It is characterized by the existence of four position turret heads movable in traverse and longitudinal directions $\left(X_{2}, Z_{2}, X_{3}, Z_{3}\right)$ and rotational axes $\left(B_{2}\right.$ and $\left.B_{3}\right)$, which replace the headstocks and tailstocks in the layouts shown above. One of the positions is occupied by opposite-placed main spindles and chucks fixed to them. One example of equipment composition of the remaining positions is presented in the figure: two spindles for internal grinding with different speed range and different wheel diameters, as well as one measuring unit for monitoring of bi-laterally placed holes in the components.

The compound carriage is equipped with two turret heads mirror-like in longitudinal direction and an external grinding spindle-motor with two grinding wheels. In this way the total number of the powered tools is increased as well as their variety. This is possible as the internal grinding spindle is removed from the carriage. In exchange for this with the layout in Fig. 4 the grinding of bi-laterally placed holes can be done with more tools.

Machining of all the right-hand placed surfaces of the component is done by placing it in the chuck of the left four-position headstock. The operation is executed by the powered tools on the left turret head, the right-hand side external grinding wheel and the tools for internal grinding on the right-hand headstock. The machining of all lefthand placed surfaces of the component is performed after its automatic setting in the chuck of the right-hand four position headstock in a way similar to the one described above. 


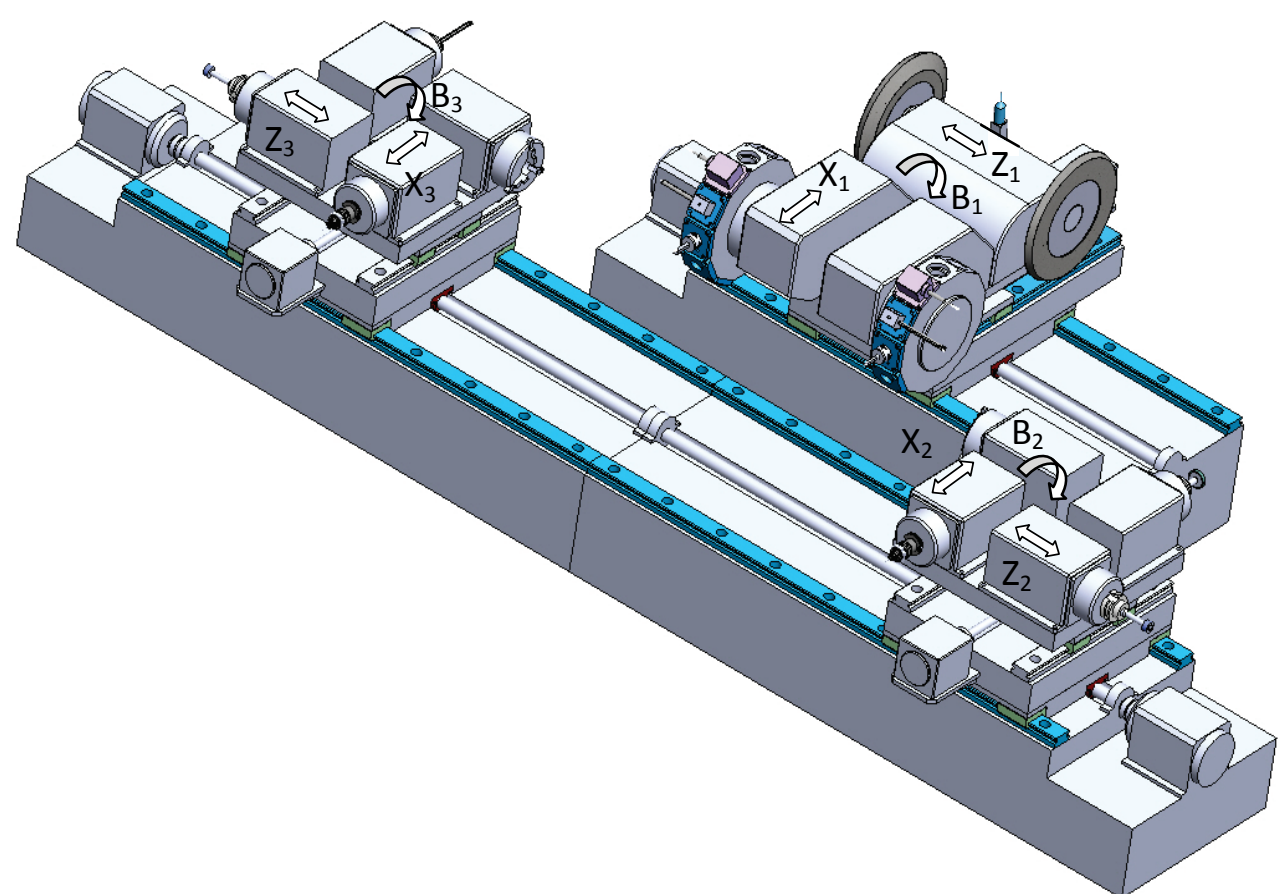

Figure 4 A single carriage machine tool for successive bi-lateral combined machining of chuck-type components

\section{3D-layouts of two carriage machine tools for combined machining}

This section presents typical representatives of 3Dlayouts of two-carriage machine tools for execution of the same technological tasks, as those with a single carriage, but providing higher productivity.

In Fig. 5 a 3D-layout is shown of a machine tool for consecutive combined machining of all one-sided surfaces of chuck type components.
Typical for it is the presence of two parallel guideways for guidance of the grinding and turning carriages placed on both sides of the workpiece. In this way all guideways and feed drives for rough and finish machining are separated, which achieves and maintains a high accuracy of the shape and dimensions of machined components.

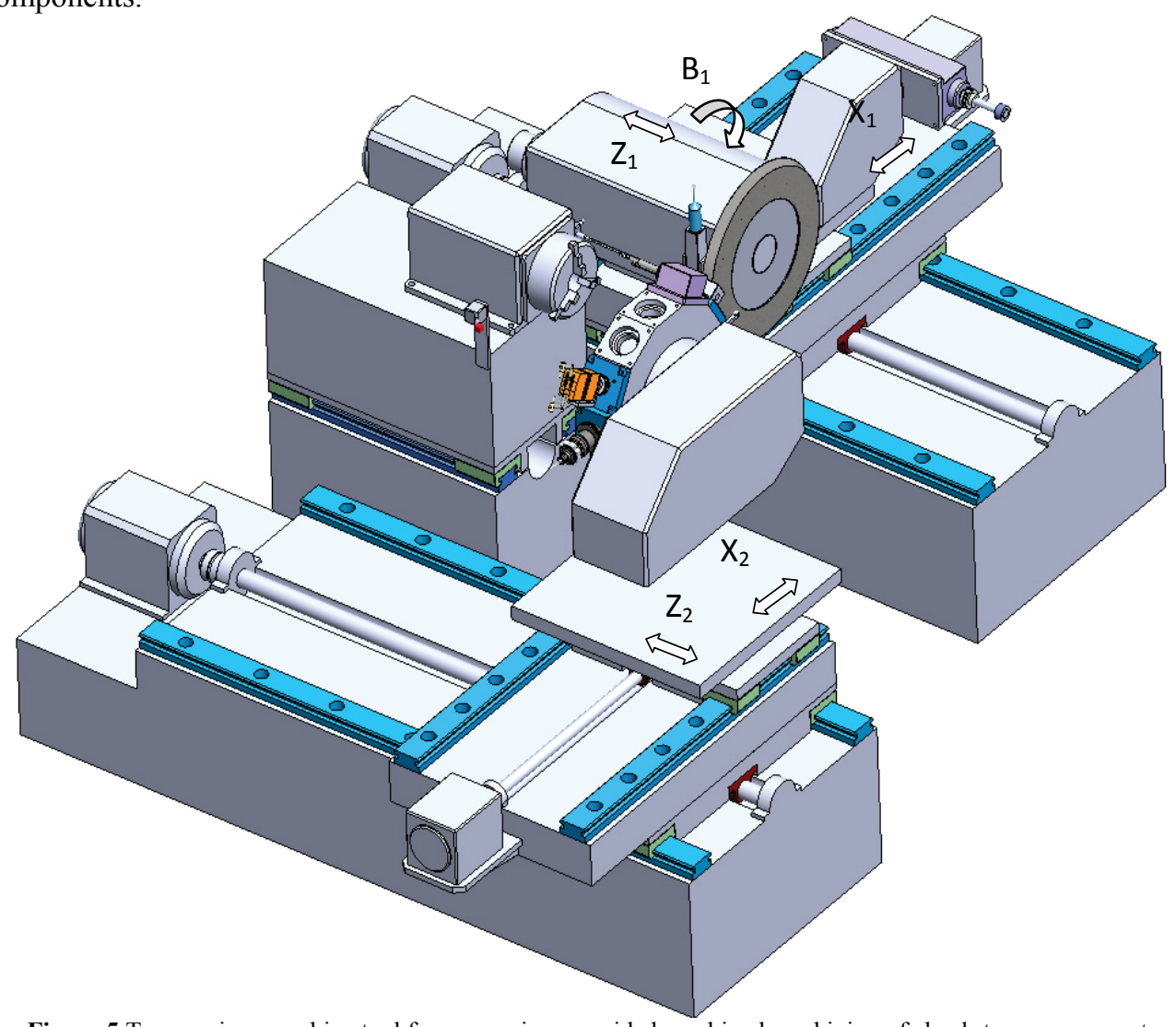

Figure 5 Two carriage machine tool for successive one-sided combined machining of chuck-type components 
This layout permits manufacturing of a machine with minimal longitudinal dimensions and respectively least occupied production area. The time to position the carriage is reduced compared to the known layouts of combined machine tools with a common longitudinal slide carrying both carriages. It is possible to fix a device for an in-process inspection of the grinded surfaces in one of the positions of the turret head and usage of $X_{2}$ axis for its movement at grinding [12]. The layout presented in Fig. 5 like the one shown in Fig. 3 can be used as a basis when establishing the idea for a general purpose machine tool for combined machining in random sequence of chuck and centre-to-centre components by adding a module and tailstock with or without $Z_{3}$ axis and a longer bed - Fig. 6. With it only one of both modules will stay (tailstock or internal grinding spindle) when changing the type of the workpieces to be machined (chuck or centreto-centre type). The suggested type of a general purpose machine tool for combined machining as the one presented in Fig. 3 is applicable in any machine-building company for production of stepped rotary type components.

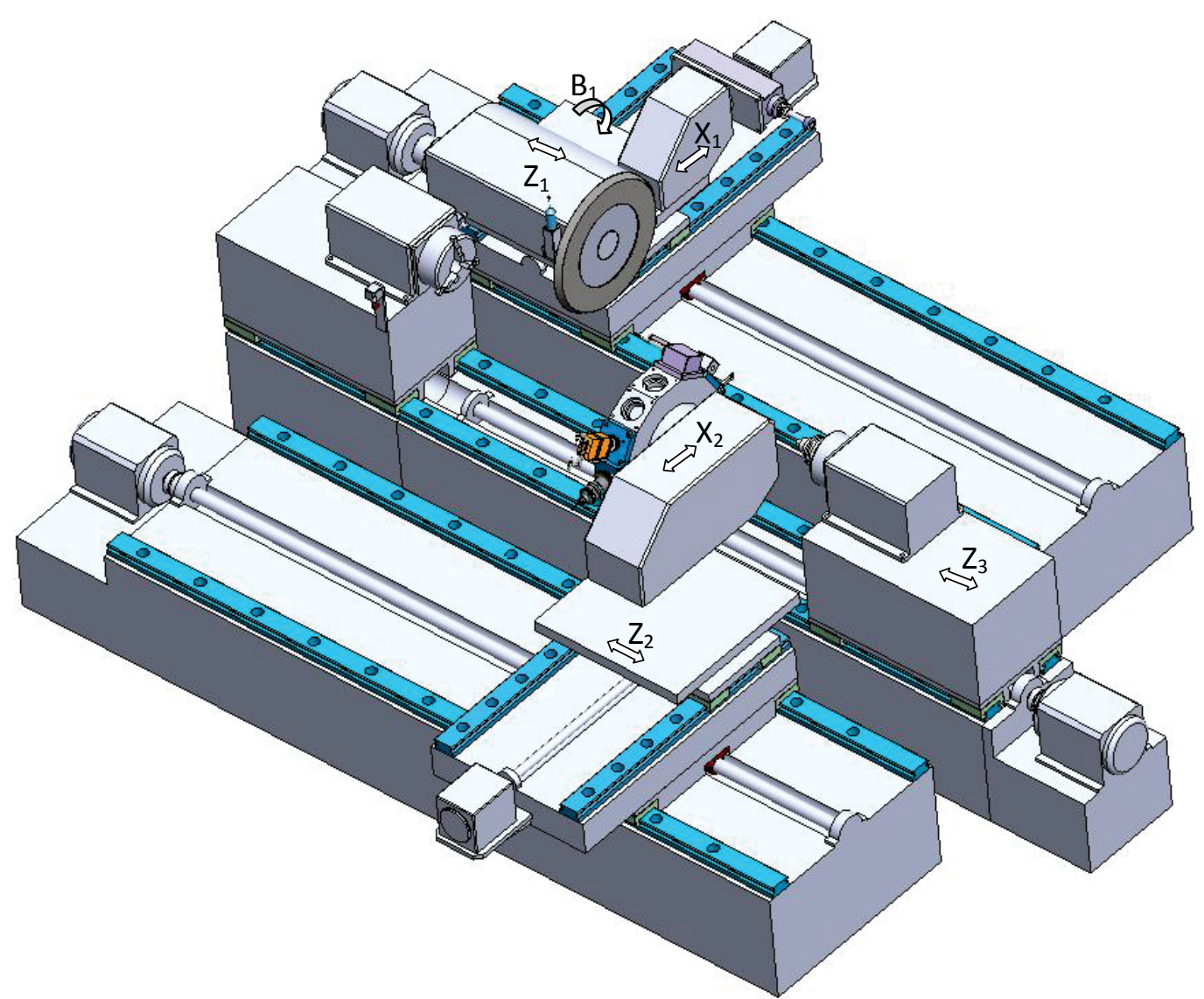

Figure 6 General purpose two carriage machine tool for consecutive one-sided combined machining in random sequence of chuck and centre to centre type components

In Fig. 7 a 3D-layout is presented of a two carriage machine tool for consecutive combined machining of all two-sided placed surfaces of chuck type components. Here the grinding carriage is equipped with two external grinding wheels and two external grinding spindles with different rotational speed and wheels with different dimensions. The turning carriage has two turret heads for cutting tools and measuring instruments.

On the third guideway parallel to the other two a tailstock $\left(Z_{3}\right.$ axis) moves with an opposite spindle unit with a chuck. This layout enables consecutive rough and finish machining of right- and left-hand sided surfaces of workpieces at their fixing in the chucks of the headstock and the tailstock. During the rough machining of the lefthand surfaces of the first component from the batch clamped in the opposite spindle, it is possible to machine a second workpiece clamped in the chuck on the headstock.

In Fig. 8 a 3D-layout of a two-carriage machine tool is shown with mirror placement of the carriages with regard to an axis of symmetry dividing the work zone in traverse direction. Both turret compound carriages in design and tooling are equal to those used in single carriage machine tools. In this layout it is possible to perform rough and finish machining of right-hand surfaces of a second workpiece from the batch fixed in the headstock simultaneously with the rough and finish machining of left-hand surfaces of the first component fixed to the tailstock.

In the layout shown in Fig. 9 both turret compound carriages are placed on both sides of the machined component and are moving along two guideways parallel to the common axis of the spindle units of both headstocks.

The layouts in Fig. 8 and 9 differ from all the rest by a higher productivity achieved by the simultaneous machining of right-hand and left-hand placed surfaces of chuck type workpieces. Furthermore, with two-carriage machine tools all tools for rough and finish machining are clamped in the turret heads and grinding spindles on the 
carriages. This permits both headstocks to be equipped with a single spindle unit placed one opposite to the other. Additionally, the front headstock is fixed to the machine tool's bed. This increases the overall rigidity of the system "workpiece-tool" making it possible to enable more intensified modes of machining at rough machining and thus to increase productivity.

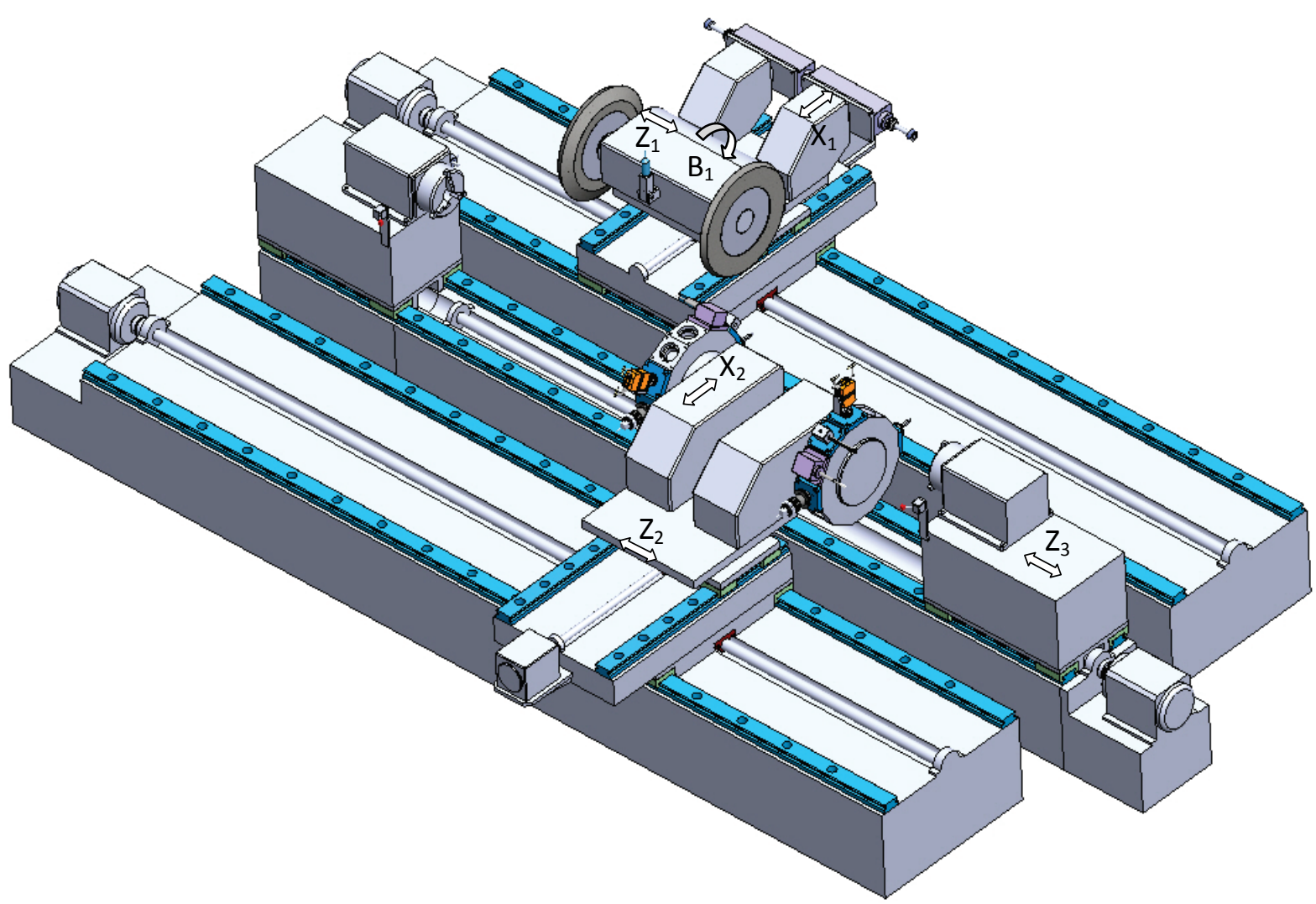

Figure 7 Two carriage machine tool for consecutive two-sided combined machining in random sequence of chuck type components

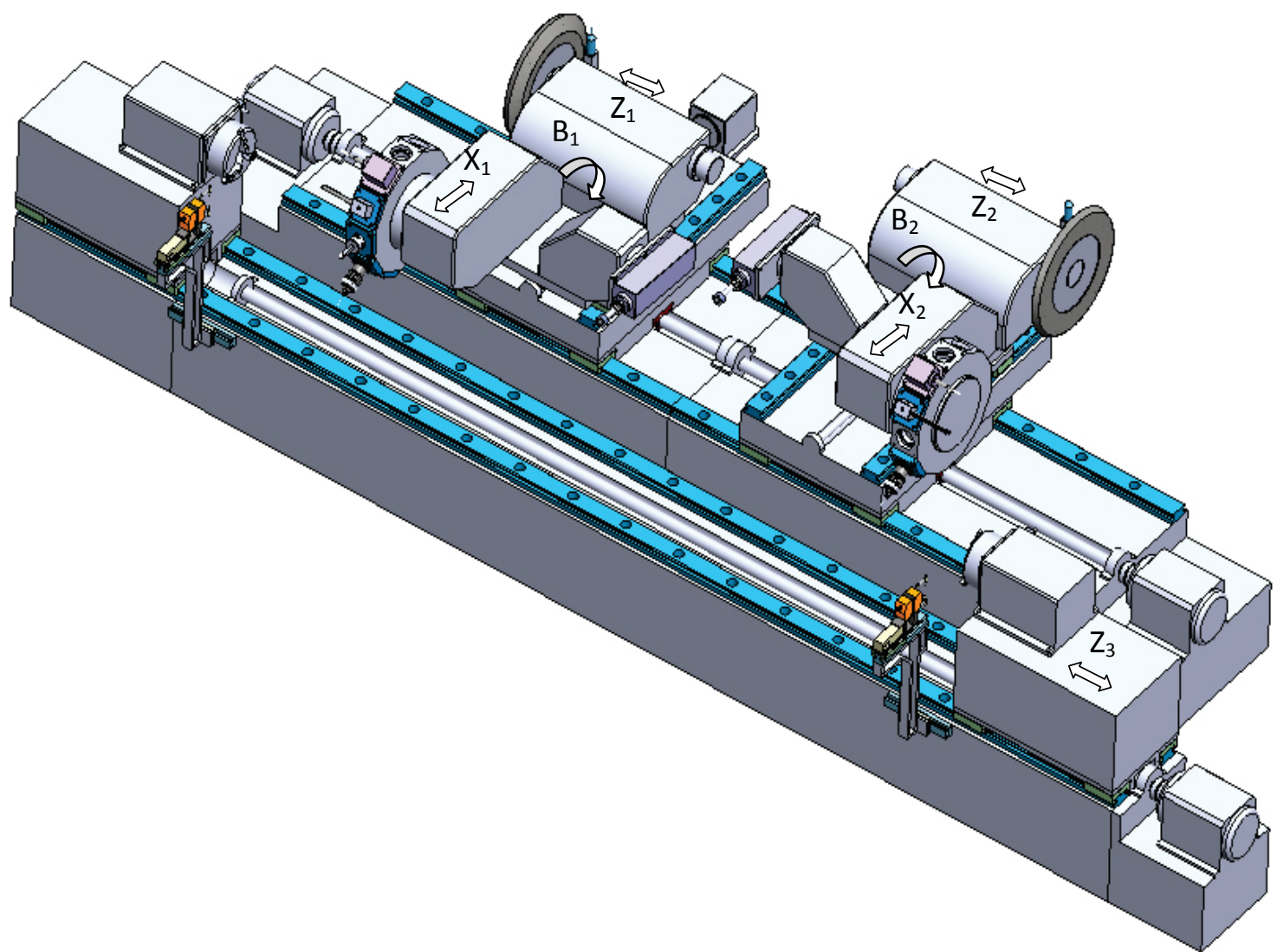

Figure 8 Two-carriage machine tool for simultaneous bilateral combined machining of chuck type components (with one-sided placement of the carriages) 


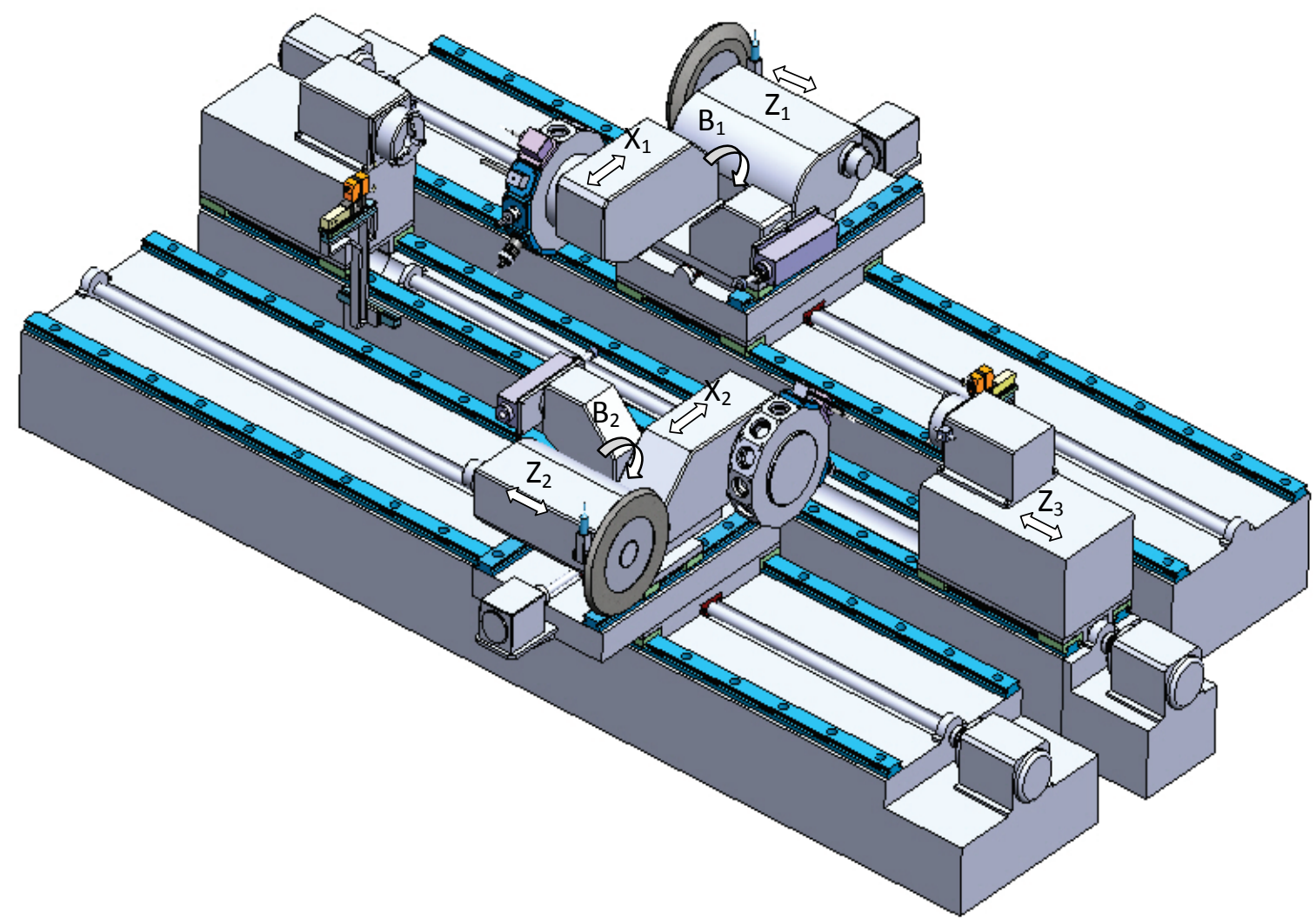

Figure 9 Two-carriage machine tool for simultaneous bilateral combined machining of chuck type components (with bilaterally placed carriages)

The presented combined machines in this publication can be used also for turning and grinding of hardened details. The turning operation of hardened workpieces cannot replace the automated grinding of large series of parts with requirements for very narrow tolerance of a few micrometres (eg. 2 to $5 \mu \mathrm{m}$ ). The reason for this is that by turning cannot be applied measurement of the workpiece surface during the cutting, and adaptively to maintain high accuracy of the diameter.

Module for laser processing can be also installed to one of the supports. It is particularly useful if it is applied to laser hardening, instantly after turning work. After this the workpiece must be grinding in the same clamping position.

The turning and grinding operations are running usually on two separate machines. The price of one combined machine, in comparison with the investment cost of one turning (and milling) centre and one digital grinding machine, with the same technological options, is not so high for the following reasons:

By the presented combined machines there are used only one headstock, only one tailstock (or counter spindle) and only one system for numerical control. The number of these modules and many others is doubled by the two other numerical turning and grinding machines. The combined machines are managed by only one operator. The machine dimensions are reduced. Each embodiment of the presented combined machines is cheaper in comparison with their analogues of two separate numerical turning and grinding machines with the same technological capabilities.

The price of the presented concepts of the combined machines and the investment costs of them is increased with the increasing number of modules that are used. This also applies to the technological capabilities of these machines in the different types of production.

Many of the presented models of the machines are configured and these can be reconfigured automatically by using the specially developed program. The user can configure a large number of variants with different technology options and prices by using an interactive menu.

\section{Conclusion}

In the paper is presented a concept for design of different 3D-layouts of one- and two-carriage machine tools for combined machining of chuck and centre to centre type workpieces based on a modular principle. New 3D-layouts are offered for consecutive or simultaneous, one-sided or bilateral machining of chuck and centre-to-centre type components.

In the second part of this article that will be published, are analysed the advantages and some disadvantages of machine concepts produced by leading companies or illustrated in this publication. There is presented a new optimized machine arrangement where these disadvantages have been removed.

\section{References}

[1] Stoev, L. Zh. Conceptions of Multitask Machines for Rotary Parts. // Machine building and electrical engineering - Journal of Mechanical Engineering. 4(2014), pp. 26-30.

[2] Stoev, L. Zh. Conceptions of two Carriages Multitask Machines for Rotary Parts. // Machine building and Electrical Engineering - Journal of Mechanical Engineering. 5-6(2014), pp. 26-30. 
[3] Patev, Hr. Improvement of the Diagram Reasons - Result at the Examination in the Unsatisfactory Quality of the Products and the Machines of Production Technique. // Ariadne. Scientific Research. (2004), 2. http://press.swu.bg/volume-collection/volume-2.aspx. (10.10.2014).

[4] Pampus, A.; Klocke, F. Kombiniertes Bearbeiten wellenförmiger Bauteile. // Ariadne. Werkstatstechnikonline (2004) 6. http://www.werkstattstechnik.de/ wt/article.php?data[article_id] $=771 .(05.04 .2013)$

[5] Tuffensammer, K. Die automatisierten Fertigungssystemen. // TZ für Metallbearbeitung - International Technical Journal for Practical Metalworking. 79(1985), H. 8, pp. 4852.

[6] Stoev, L. Method and Machine Tool for Multi-Operational Machining of Rotary Components, BG-Patent № 66427 B1. (2014). http://worldwide.espacenet.com/publicationDetails/ originalDocument $? \mathrm{CC}=\mathrm{BG} \& \mathrm{NR}=66427 \mathrm{~B} 1 \& \mathrm{KC}=\mathrm{B} 1 \& \mathrm{FT}=$ $\mathrm{D} \& \mathrm{ND}=4 \&$ date $=20140430 \& \mathrm{DB}=$ worldwide.espacenet.co m\&locale $=$ en_EP. $(10.10 .2014)$.

[7] Aleksandrova, I. Finishing Technologies. Vasil Aprilov University Publishing House, Gabrovo, 2013.

[8] Aleksandrova, I. Methodology of Modeling, Identification and Control of Grinding Process. // Engineering sciences Journal of the Bulgarian Academy of Sciences. 2(2010), pp. 60-72.

[9] Aleksandrova, I. Modeling and Control of the Qualitative Parameters of the Grinding Process. // Engineering sciences - Journal of the Bulgarian Academy of Sciences. 1(2012), pp. 66-75.

[10] Stambolov, Gr. Methodology a Development of Reconfigurable Manufacturing Systems. Dissertation, TUSofia, 2005.

[11] Heisel, U.; Braun, S.; Dressler, M.; Eisseler, R.; Klotz, D.; Maier, D.; Maier, W.; Schaal, M.; Schleich, B.; Stehle, T. Innovationen und Trends im Werkzeugmaschinenbau. // Journal of the Technical University at Plovdiv. Bulgaria, 13(2006), pp. 5-22.

[12] Stoev, L. Zh.; Hristov, St. Method for In-process Control at Longitudinal Grinding. // Machine building and Electrical Engineering - Journal of Mechanical Engineering. 1(2014), pp. $46-50$.

\section{Authors' addresses}

Lachezar Stoev, Assoc. Professor, PhD

Technical University of Sofia,

Faculty of Industrial Technology,

Faculty of German Engineering Education and Industrial

Management,

8 Kl. Ohridski Blvd., 1000 Sofia, Bulgaria

E-mail: 1stoev@tu-sofia.bg

\section{Stoil Bozhikov, PhD student}

Technical University of Sofia,

Faculty of Industrial Technology,

8 Kl. Ohridski Blvd., 1000 Sofia, Bulgaria

E-mail: stoilbozhikov@gmail.com 